\title{
EFFECT OF INTERCROPPING ON THE DEVELOPMENT OF CASSAVA BACTERIAL BLIGHT
}

\author{
FANOU André Antoine ${ }^{1 *}$, WYDRA Kerstin ${ }^{2}$ \\ ${ }^{1}$ Faculty of Agronomy, University of Parakou, BP 123 Parakou, Republic of Benin \\ ${ }^{2}$ Erfurt University of Applied Sciences, Erfurt, Germany \\ Received - March 04, 2018; Revision - May 01, 2018; Accepted - June 11, 2018 \\ Available Online - June 20, 2018 \\ DOI: http://dx.doi.org/10.18006/2018.6(3).531.537
}

KEYWORDS
Cassava
Intercropping
Bacterial disease
Maize
Cowpea
Xanthomonas axonopodis pv.
manihotis
manihotis

\begin{abstract}
The effect of intercropping cassava with maize or cowpea in two arrangements i.e. both crops in the same row or in alternate rows, on cassava bacterial blight has been compared to cassava monoculture in the forest-savannah transition zone of Nigeria using a randomized complete block design. Result of study revealed that in cassava monoculture, more severe disease symptoms developed than in intercropping patterns. Further, following order of disease severity: cassava monoculture > cassavacowpea in alternate rows > cassava-cowpea in the same row > cassava-maize in alternate rows > cassava-maize in the same row have been reported. The highest reduction in disease severity (53\%) was observed in cassava intercropped with maize in the same row or in alternate rows (disease indices 8.4) compared to cassava monoculture (disease index 18.0). Generally, growth parameters and yields of cassava roots were not significantly differed in various cropping patterns. However, the combination of cassava root yield and maize grain yield may provide more yield stability and cash income to the farmer than cassava monoculture.
\end{abstract}

* Corresponding author

E-mail: andrefanou@gmail.com (FANOU André Antoine)

Peer review under responsibility of Journal of Experimental Biology and Agricultural Sciences.

Production and Hosting by Horizon Publisher India [HPI] (http://www.horizonpublisherindia.in/).

All rights reserved.
All the article published by Journal of Experimental Biology and Agricultural Sciences is licensed under a Creative Commons Attribution-NonCommercial 4.0 International License Based on a work at www.jebas.org.

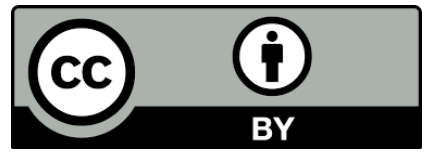




\section{Introduction}

Cassava Bacterial Blight (CBB) a devastating disease is caused by Xanthomonas axonopodis pv. manihotis (Xam) (Vauterin et al., 1995 ; Fanou et al., 2018). It is one of the major diseases affecting cassava (Lozano \& Booth, 1974; Rubio et al., 2017). CBB is the second most devastating disease after Cassava Mosaic Virus Disease Complex and may cause more damage to the crop than any other bacterial disease (McCallum et al., 2017).

Symptoms comprise leaf spots and blight as well as systemic symptoms such as stem cankers and dieback of sprouts, twigs or the whole plant. The severity of symptoms varies widely with the cultivar, ecology, year and virulence of the strain (Mutka et al., 2016). In fact, the majority of $X$. axonopodis pv. manihotis (Xam) strains collected from West-Africa were highly virulent (Wydra et al., 1998a) and caused more than 50\% root yield losses under favourable conditions in Sub-Saharan Africa (Fanou, 1999). Heavy epidemics were reported during the last two decades surveys in five West-African countries with regionally severe outbreaks (Wydra \& Msikita, 1998; Banito et al., 2001; Wydra \& Verdier 2002).

Breakdown of plant resistance was frequently observed in cassava in the last few years (Wydra et al., 1998b; Zinsou, 2001). It is supposed that the increase in epidemics in last two decades was due to the appearance of new X. axonopodis pv. manihotis (Xam) strains in areas with high infection pressure, where predominantly resistant cultivars are grown, such as some regions in Nigeria (Arene, 1990). Many authors reported high genotype, strain and environmental interactions affect the disease severity (Restrepo et al., 1999; Restrepo et al., 2000; Zinsou, 2001; Wydra et al., 2001a). Thus, disease management through host plant resistance revealed unsatisfactory. Additionally, weeds, infected debris (Fanou et al., 2017) and vectors (Fanou, 1999; ZandjanakouTachin et al., 2007) as well as infected planting material contribute in the dissemination of the disease. Therefore, according to Wydra et al. (2001b) an integrated management strategy may play a promising role in control of CBB disease.

One important element of an integrated control system in the tropics is intercropping, which is still the predominant cropping pattern in Sub-Saharan Africa. Of the total area under cultivation in Africa more than $75 \%$ have been under mixed cropped (Nweke et al., 1994). Nevertheless, monoculture of cassava is increasingly practiced in many areas, often on marginal soils and under unfavourable climatic conditions, favouring the occurrence of epidemics of cassava bacterial blight. In Benin, more than $60 \%$ of the farmers intercrop cassava and maize (Biaou \& Issiaka, 1997), the most common cassava production system in the tropics, but farmer also used okra, cowpea, bean, and groundnut intercropping system. Intercropping increases the total productivity per unit land and thus can provide more cash income to farmers. The influence of cassava and vegetable intercropping on development of diseases was studied in tropical America (Larios \& Moreno, 1976; Larios \& Moreno, 1977; Moreno, 1979) and in Asia (Ghosh et al., 1986), but reports on intercropping as measure to control diseases in tropical Africa are in scarcity. Ahohuendo \& Sarkar (1995) reported partial control of African cassava mosaic disease by intercropping, but intercropping cowpea with maize or cassava did not show a clear effect on cowpea bacterial blight, though an additional yield from the minor crop could compensate losses (Sikirou, 1999). However, Zinsou et al. (2004) observed a reduced severity of cassava bacterial blight when soil amendements were combined with intercropping practice and planting date. Bacterial diseases are generally disseminated in the field by rain splash and aerosols combined with wind. Therefore, intercropping could have a barrier effect to inhibit the transport of the inoculum. Intercropping was proposed as measure to control cassava bacterial blight in the dry savannah (Tabot, 1995) and in the humid forest (Arene, 1976), but data including detailed evaluations of symptom development, plant growth parameters and root yield, especially from the forest savannah transition zone, where the disease is more pronounced than in the rainforest (Wydra \& Msikita, 1998), are lacking. The objective of the present studies is to evaluate intercropping cassava as cultural component of an integrated strategy to control CBB.

\section{Material And Methods}

\subsection{Experimental site}

The intercropping studies were conducted at the International Institute of Tropical Agriculture (IITA), Ibadan (Federal Republic of Nigeria) located in the forest-savannah transition zone characterized by tropical humid climate with an average annual rainfall ranging between 1100 to $1300 \mathrm{~mm}$ spread from March to July and from September to November intercalated by a small dry season in August. The temperature ranged between $20.11^{\circ} \mathrm{C}$ to $41^{\circ} \mathrm{C}$, and soil type is dominance lixisoils or regosoils.

\subsection{Experimental design}

Study area was split in plots arranged in a randomized complete block design with three replications. Plot size for cassava monoculture was $9 \mathrm{~m} \mathrm{X} 9 \mathrm{~m}$. Ploughing ridges were $1 \mathrm{~m}$ spaced. But, in intercropping, ploughing ridges were $0.5 \mathrm{~m}$ spaced so that the total number of ridges was 18 . Five treatments have been defined and consisted as cassava sole crop $(\mathrm{Ca})$, cassava plants intercropped with cowpea within the same row $(\mathrm{CaCoS} 1)$, cassava intercropped with cowpea in alternating rows $(\mathrm{CaCoS} 2)$, cassava intercropped with maize plants within the same row (CaMS1), cassava intercropped with maize in alternating rows (CaMS2). Spacing between various plots to plots were $2 \mathrm{~m}$ and ridges to 
ridges were $1 \mathrm{~m}$ in monocropping and $0.5 \mathrm{~m}$ in intercropping. Stems of the susceptible local cassava cultivar TME1 were collected from a one-year old cassava field from apparently bacterial blight-free plants at the IITA station. Cuttings of about $20 \mathrm{~cm}$ length were planted. In each plot, cassava was considered as base crop and was planted with $1 \mathrm{~m}$ spacing $(10,000$ plants ha$\left.{ }^{1}\right)$. Maize was planted with $0.5 \mathrm{~m}$ spacing in rows $(20,000$ plants $\mathrm{ha}^{-1}$ ), and with $0.6 \mathrm{~m}$ when cropped on rows alternating with rows of cassava $\left(33,333\right.$ plants ha $\left.{ }^{-1}\right)$. Cowpea was sown with $0.5 \mathrm{~m}$ spacing in rows with cassava $\left(20,000\right.$ plants $\left.\mathrm{ha}^{-1}\right)$ and when cropped on rows alternating with rows of cassava. One border row surrounding each plot was planted with cultivar TME1.

\subsection{Maintenance and plant inoculation}

After three weeks of planting, dead cuttings were replaced with new ones. Weeding was done manually in the rainy season. In cowpea plots, the insecticide Karate Super (mixture of Lambdacyhalothrin $20 \mathrm{~g} / \mathrm{l}$ and Dimethoate $40 \mathrm{~g} / \mathrm{l}$ ) was sprayed at the dose of 0.4 1/ha to control cowpea pests. In cassava monoculture and intercropping treatments, the fertilizers urea, supertriple $\left(\mathrm{P}_{2} \mathrm{O}_{5}\right)$, and potassium chloride were applied in bands with $65 \mathrm{~kg}, 67 \mathrm{~kg}$, and $100 \mathrm{~kg}$ per ha respectively. The bordering cassava plants were sprayed using Xanthomonas axonopodis pv manihotis suspension at the concentration of $10^{7} \mathrm{cfu} / \mathrm{ml}$. Suspension was then applied on the leaf abaxial surface in the evening, one month after planting.

\subsection{Symptom evaluation}

Percentages of leaves with angular spots, blight or leaf drop/wilt along with percentage of shoot tips or stems with apical dieback were recorded monthly, started from the one month after inoculation and carried out until symptoms disappeared during the dry season, and twelve months after planting during harvest, by counting leaves with the respective symptom type on ten plants per plot selected at random. Leaves showing more than one symptom type were considered as the most infested one while leaf spots and blight symptoms were classified as a blighted one. Symptom was evaluated using the following percentage scales: $\leq$ $5 \%, 5-10 \%, 10-20 \%, 20-50 \%, 50-80 \%$ and $80-100 \%$. Data processing was performed using mean values for each interval. Disease index (ds) was calculated by the formula given by Winstead \& Kelman (1952): ds $=(1 \times \mathrm{S}+2$ x B +3 x W + 4 x D)/ 10 , where $\mathrm{S}, \mathrm{B}, \mathrm{W}$ and $\mathrm{D}$ are the percentage of leaves with spots, blight, wilt/drop and stems with dieback, respectively. Based on such formula, the highest severity value would be 63 [e.g. evaluation of $80-100 \%$ wilt and $80-100 \%$ dieback corresponds to $(1 \times 0+2 \times 0+3 \times 90+4 \times 90) / 10]$.

\subsection{Growth parameters}

Cowpea and maize were harvested when the pods and ears were mature, three and four months after planting for each crop, respectively. On the other hand, cassava was harvested twice in a year. Five cassava plants randomly selected per plot were harvested six months after planting, while ten plants were harvested per plot twelve months after planting. In parallel, various growth parameters such as plant height, dropped leaves, total number of leaves, number of spotted, blighted and wilted leaves and root, stem and leaf fresh and dry weights were also recorded. Leaves, stems and roots were harvested separately and weighed. Leaf, stem and root samples from 5 or 10 plants were mixed separately, and subsamples were cut into small pieces and dried at $105^{\circ} \mathrm{C}$ during 72 hours for determination of dry weight.

\subsection{Statistical analyses}

Data were subject to statistical analysis using the contrast statement method of the Mixed Model of SAS Software (Statistical Analysis System). Percentage data were square-root transformed prior to the analysis while yield and plant growth data were log-transformed. The least significant differences (LSD) test was used for mean separation, following the analysis of variance (ANOVA).

\section{Results}

\subsection{Development of spots, blight and disease severity}

The incidence of leaves with spots was low in both cassava-maize intercropping patterns, while it increased in all other patterns between months 2-4 after planting (Figure 1 A). The slight increase was recorded in the patterns cassava-maize in the same row and in alternate rows four months after planting occurred after harvesting the intercropped maize. The number of blighted leaves generally decreased between two and three months after planting due to a short dry season (Figure $1 \mathrm{~B}$ ). Over the first 6 months after planting the cassava monoculture system reached the highest numbers of leaves with blight. During the dry season between 6-11 months after planting spot and blight symptom development ceased and diseased leaves dropped, therefore, wilted and dropped leaves were still recorded (data not shown). The significantly $(\mathrm{p}<0.05)$ highest incidences of leaves with spots and blight were recorded in cassava monoculture, while the lowest incidence of leaves with spot, blight and wilted/dropped leaves were observed in cassava-maize intercropping patterns (Table 1). Only few dieback symptoms occurred in all treatments.

Disease index was significantly lower in cassava intercropped with maize than in the other patterns in 2-5 months after planting (Figure $1 \mathrm{C}$ ) and averaged over the whole period (Table 1). 

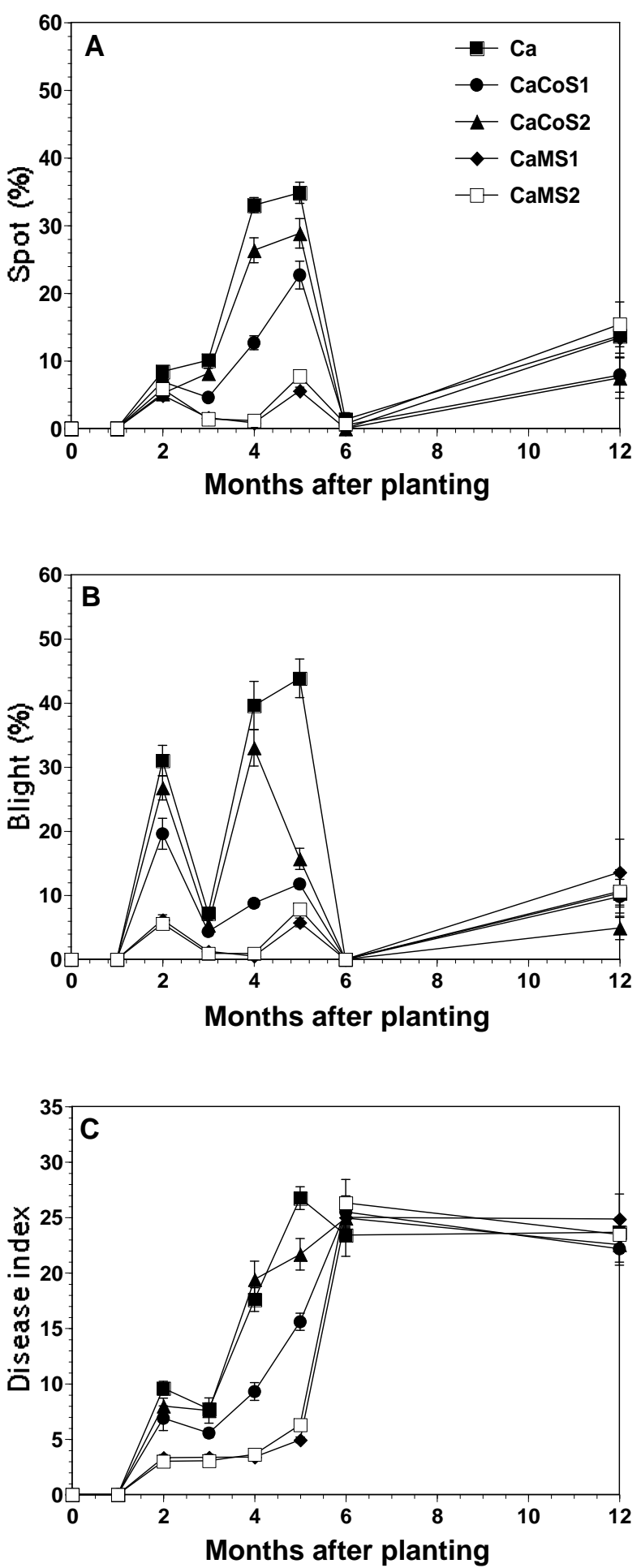

Figure 1 Incidences of leaves with spots (A), blight (B) and disease index $\mathrm{x}^{\mathrm{z}}(\mathrm{C})$ in five cropping patterns over the cassava growing period; $\mathrm{Ca}=$ cassava monoculture, $\mathrm{CaCoS} 1$ = cassava-cowpea in the same row, $\mathrm{CaCoS} 2$ = cassava-cowpea in alternate rows, $\mathrm{CaMS} 1$ = cassava-maize in the same row, CaMS2 = cassava-maize in alternate rows. Vertical bars represent the standard error of the mean of three replications.
Table 1 Effect of five cropping patterns on the incidence and various disease index of Cassava Bacterial Blight

\begin{tabular}{|clllll|}
$\begin{array}{c}\text { Cropping } \\
\text { pattern }\end{array}$ & Spot & Blight & Wilt & Dieback & $\begin{array}{l}\text { Disease } \\
\text { index }\end{array}$ \\
\hline $\mathrm{Ca}$ & $14.1 \pm 0.51^{\mathrm{a}}$ & $17.5 \pm 1.32^{\mathrm{a}}$ & $33.6 \pm 0.94^{\mathrm{a}}$ & $0.5 \pm 0.15^{\mathrm{ab}}$ & $18.0 \pm 1.15^{\mathrm{a}}$ \\
\hline $\mathrm{CaCoS} 1$ & $7.2 \pm 0.57^{\mathrm{b}}$ & $7.30 \pm 0.56^{\mathrm{c}}$ & $30.7 \pm 0.90^{\mathrm{a}}$ & $0.5 \pm 0.10^{\mathrm{ab}}$ & $13.2 \pm 1.15^{\mathrm{b}}$ \\
\hline $\mathrm{CaCoS} 2$ & $9.4 \pm 0.72^{\mathrm{b}}$ & $10.8 \pm 0.61^{\mathrm{b}}$ & $33.0 \pm 0.57^{\mathrm{a}}$ & $1.0 \pm 0.0^{\mathrm{a}}$ & $16.8 \pm 1.30^{\mathrm{a}}$ \\
\hline $\mathrm{CaMS} 1$ & $2.6 \pm 0.11^{\mathrm{c}}$ & $2.2 \pm 0.11^{\mathrm{d}}$ & $22.4 \pm 0.93^{\mathrm{b}}$ & $0.4 \pm 0.05^{\mathrm{ab}}$ & $8.4 \pm 0.40^{\mathrm{c}}$ \\
\hline CaMS2 & $3.3 \pm 0.12^{\mathrm{c}}$ & $2.6 \pm 0.11^{\mathrm{d}}$ & $22.6 \pm 0.81^{\mathrm{b}}$ & $0.3 \pm 0.05^{\mathrm{b}}$ & $8.4 \pm 0.87^{\mathrm{c}}$ \\
\hline
\end{tabular}

Data in the table were square-root back-transformed and can therefore not be used to calculate ds; Ca = cassava monoculture, $\mathrm{CaCoS} 1=$ cassava-cowpea on the same row, CaCoS2 = cassava cowpea on alternate rows, CaMS1 = cassava-maize on the same row, CaMS2 = cassava-maize on alternate rows; Means followed by the same letter( $(s)$ within a column are not significantly different at $p=$ 0.05 according to the least significant difference test. Means represent the average of six evaluation dates obtained from 3 repeated plots. Due to square root transformation, disease index - which was calculated per plant - cannot be calculated using the means of symptom incidences in table.

Disease index was high also in the dry season due to the high number of wilted and dropped leaves. Overall reported pattern of severity are monoculture $(\mathrm{Ca})>$ cassava-cowpea in alternate rows $(\mathrm{CaCoS} 2)>$ cassava-cowpea in the same row $(\mathrm{CaCoS} 1)>$ cassava-maize in alternate rows (CaMS2) > cassava-maize in the same row (CaMS1). In the pattern cassava-maize in the same row the percentages of leaves with spots, blight, wilt, stems with dieback, and disease index were reduced by $81.3 \%, 87.7 \% 33.4 \%$, $30.2 \%$ and $53.7 \%$, respectively, compared to cassava monoculture.

\subsection{Effect of cropping system on plant growth}

In general, any significant differences were not observed between treatments for root, stem and leaf fresh and dry weights at six and twelve months after planting (Table 2). Only at six months after planting, root and stem dry weights were significantly lower in the pattern cassava-maize in the same row compared to in the cassava monoculture system.

\section{Discussion and Conclusions}

Results from the current study indicated that the percentage of leaves with spots, blight and disease severity were significantly reduced in all the intercropping patterns compared to cassava monoculture. Best suppressive effects were achieved in cassava intercropped with maize, where maize plants formed a physical barrier of a height of more than $2 \mathrm{~m}$. Moreover, cassava plants in these plots were etiolated with long internodes, and contact between leaves as well as to the soil was limited, thus reducing the dissemination of the pathogen. The higher reduction observed 
TABLE 2 Fresh and dry weights of cassava roots (FR, DR), leaves (FL, DL) and stems (FS, DS) (t/ha) in five cropping patterns six and twelve months after planting

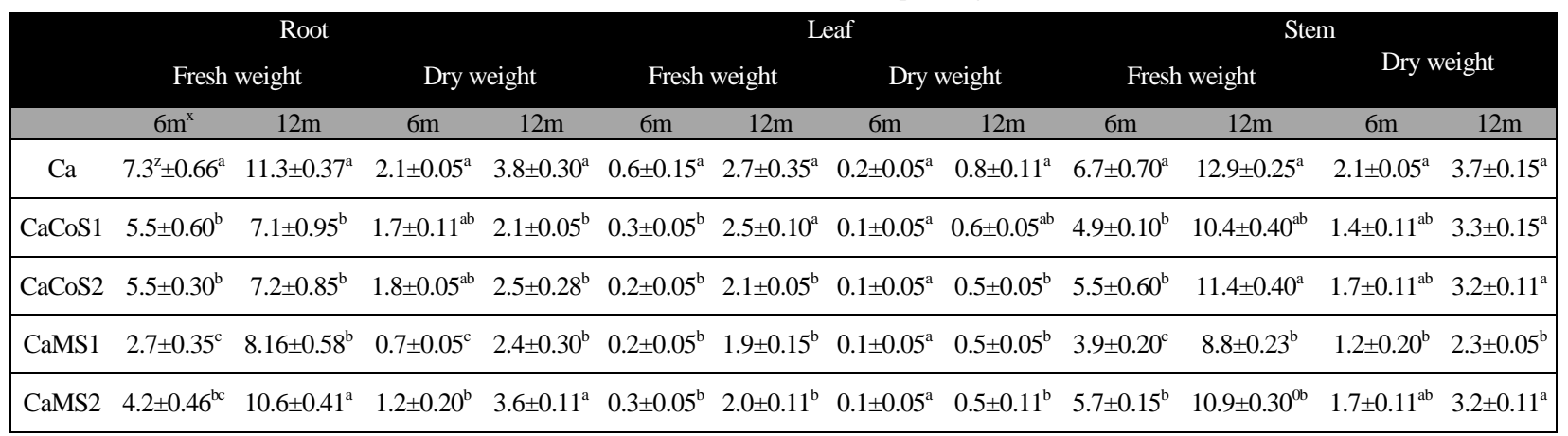

${ }^{x}$ Harvests at six and twelve months; Ca = cassava monoculture, CaCoS1 = cassava-cowpea on the same row, CaCoS $2=$ cassava-cowpea on alternate rows, CaMS1 = cassava-maize on the same row, CaMS2 = cassava-maize on alternate rows; Means followed by the same letter(s) within a column are not significantly different at $p=0.05$ according to the least significant difference test. Means represent the average of six evaluation dates obtained from 3 repeated plots. Means were $10^{x}$ back-transformed.

in systems intercropped in the same row compared to intercropping in alternate rows was probably due to the limitation of dissemination of the pathogen between cassava plants along the rows by rain-splash and wind.

Modifications of the micro-environment and nutrient uptake by intercropping may influence the development of diseases (Trenbath, 1976). A reduction of bacterial blight incidence and severity in cassava intercropped with maize and melon in the humid forest and with maize in the dry savannah was also reported by Arene (1976) and Tabot (1995), respectively. Maize is not the only cereal that, intercropped with cassava, reduces CBB development. In fact, when Zinsou et al. (2004) had intercropped cassava with sorghum in two ecozones, they obtained CBB reduction varying from 25 to $45 \%$ depending on planting time, year and ecozone. Besides the decrease of bacterial blight under the cassava-maize intercropping system, Larios \& Moreno (1976) and Moreno (1979) also observed a delay in the development of super elongation of cassava (Elsinoe brasiliensis) and of rust (Uromyces manihotis), and a reduction in the incidence and severity of mildew, super elongation, and anthracnose (Colletotrichum $s p$.) in a cassava-common bean association in Turrialba, Costa Rica, while Ghosh et al. (1986) reported a reduction of brown leaf spots (Cercosporidium henningsii) in cassava associated with Eucalyptus sp. and Leucaena sp. Intercropping was found to reduce potato infestation by Ralstonia solanacearum (Autrique \& Potts, 1987; Kloos et al., 1987) and tomato (Pan,1990). On the other hand, only a slight reduction or no reduction of bacterial wilt was obtained when tomato was intercropped with cowpea, soybean or Welsh onion (Michel et al., 1997). Similarly Sikirou (1999) did not observe significant effects of intercropping on cowpea bacterial blight when cowpea was intercropped with maize or cassava in the forest-savannah transition zone of West Africa. Moreover, Moreno (1979) did not find an effect of bean-cassava association on cassava leaf scab, rust, and Cercospora spots. However the same author reported an increased severity of powdery mildew when cassava was intercropped with maize. .

Current study did not reveal significant differences between the various cropping systems tested for cassava yield. Similar results were found by Ezumah et al. (1988) in cassava and maize intercropping. In trials of present study, at six months after planting, cassava roots in the maize intercropping patterns responded with a reduction in yield because of a partially covering of cassava plants by growing maize plants. After harvesting maize, this effect was compensated until the cassava harvest at 12 months after planting. Thus, farmers may gain from cassava intercropping having two yields - maize and cassava - and increased yield stability. In Togo, cash incomes were higher under intercropping than under monoculture (Marqette \& Pouzet, 1988). Thus, intercropping cassava with maize on alternate rows is recommended. Therefore, intercropping cassava and maize not only reduces Cassava Bacterial Blight but provides more cash income to the farmers.

\section{Acknowledgment}

We thank the Federal Ministry for Economic Cooperation and Development, Germany, for financial support and Mr. Sam Korie, IITA, Ibadan, for help in the statistical analysis.

\section{Conflict of Interest Statement}

There is no conflict of interest 


\section{References}

Ahohuendo BC, Sarkar S (1995) Partial control of the spread of African cassava mosaic virus in Benin by intercropping. Zeitschrift für. Pflanzenkrankheiten and Pflanzenschutz 102:249256.

Arene OB (1976) Influence of shade and intercropping on the incidence of cassava bacterial blight. In: Proc. Int. Workshop on Bacterial Blight. IDRC Series 09C. Pp. 28-29.

Arene OB (1990) Advances in integrated control systems of economic diseases of cassava in Nigeria. In: Hahn SK, Caveness F (Eds). Integrated Pest Management for Tropical Root and Tuber Crops. Proc. of the Workshop on the Global Status of and Prospects for Integrated Pest Management of Root and Tuber Crops in the Tropics. 25-30 October 1987, Ibadan, Nigeria. Pp. 169-175.

Autrique A, Potts PM (1987) The influence of mixed cropping on the control of potato bacterial wilt (Pseudomonas solanacearum). Annals of Applied Biology 111:125-133.

Banito A, Kpémoua K, Wydra K, Rudolph K (2001) Bacterial blight of cassava in Togo: its importance, the virulence of the pathogen and the resistance of varieties. In: De Boer, Solke $\mathrm{H}$ (Eds). 10th International Conference on Plant Pathogenic Bacteria, Charlottetown, Prince Edward Island, Canada july 2327, 2000, Kluwer Academic Publishers.. Pp. 259-264.

Biaou G, Issiaka K (1997) Production du Manioc au Benin: Contraintes pour une Meilleure Amelioration des Ressources. ESCaPP- Benin. International Institute of Tropical Agriculture, Cotonou, Bénin.

Ezumah HC, Nweke FI, Kalabare ND, Karunwi A (1988) Response of a cassava-maize intercrop to nitrogen in two-year sequential cropping. In: Cassava - Based Cropping Systems Research 1. International Institute of Tropical Agriculture, Ibadan, Nigeria. Pp. 161-175.

Fanou AA, Zinsou AV, Wydra K (2018) Cassava Bacterial Blight : A Devastating Disease of Cassava. In: Viduranga W (Ed), Cassava. INTECH. Available on http://dx.doi.org/10.5772/intechopen.71527 access on march $2^{\text {nd }} 2018$.

Fanou AA (1999) Epidemiological and ecological investigations on cassava bacterial blight and development of integrated methods for its control in Africa. PhD thesis submitted to the Georg-AugustUniversity, Goettingen, Germany. Cuvillier Verlag Pp. 199.

Fanou AA, Zinsou AV, Wydra K (2017) Survival of Xanthomonas axonopodis pv. manihotis in weed species and in cassava debris: implication in the epidemiology of cassava bacterial blight. International Journal of Advanced Research 5:2098-2112. DOI: 10.21474/IJAR01/4057

Ghosh SP, Pillai KS, Thankappan M (1986) Cassava-based multiple cropping system II. Incidence of pests and diseases. Journal of Root Crops 12:83-89.

Kloos JP, Tulog B, Tumapon AS (1987) Effects of intercropping potato on bacterial wilt. The Philippine Agriculturist 70:83-90.

Larios J, Moreno RA (1976) Epidemiologia de algunas enfermedades foliares de la yuca en diferentes sistemas de cultivo. I Mildiu polvoroso y rona. Turrialba 26:389-398.

Larios JF, Moreno RA (1977) Epidemiologia de algunas enfermedades foliares de la yuca en diferentes sistemas de cultivo. II Roya y muerte descendente. Turrialba 27:151-156.

Lozano JC, Booth RH (1974) Diseases of cassava (Manihot esculenta Crantz). Pest Articles and News Summarises (PANS) 20:30-54.

Marqette J, Pouzet D (1988) Cassava in associated cultivation on some soil (Terre de Barre) in Togo. In: INRA (Ed). Proceedings of the7th Symposium of the International Society for Tropical Root Crops. Gosier (Guadeloupe) 1 - 6 July 1985, Paris. Pp. 475482.

McCallum EJ, Anjanappa RB, Gruissem W (2017) Tackling agriculturally relevant diseases in the staple crop cassava (Manihot esculenta) Current Opinion in Plant Biology 38:50-58.

Michel VV, Wang JF, Midmore DJ, Hartman GL (1997) Effects of intercropping and soil amendment with urea and calcium oxide on the incidence of bacterial wilt of tomato and survival of soilborne Pseudomonas solanacearum in Taiwan. Plant Pathology 46:600-610.

Moreno RA (1979) Crop protection implications of cassava intercropping. In: Weber E, Nestel B, Campbell M (Eds). Intercropping with Cassava. Proceedings of the International Workshop, Trivandrum, India. IRDC. 142e. Pp. 113-127.

Mutka AM, Fentress SJ, Sher JW, Berry JC, Pretz C, Nusinow DA, Bart R (2016) Quantitative, image-based phenotyping methods provide insight into spatial and temporal dimensions of plant disease Plant Physiology Preview. Published on July 21, 2016, as DOI:10.1104/pp.16.00984.

Nweke FI, Dixon AGO, Asiedu R, Folayan SA (1994) Attributes of cassava varieties desired by farmers in sub-Saharan Africa. In: Akoroda MO (Ed.), Proceedings of the 5th Symposium of the 
International Society for Tropcal Root Crops, Africa Branch, Kampala, Uganda, 22-28 November 1992. Pp. 65-92.

Pan LY (1990) Effect of welsh onion on bacterial wilt of tomato and survival of Pseudomonas solanacearum in soils. MSc thesis submitted to Taiwan National Chung Hsing University, Taichung.

Restrepo S, Duque MC, Tohme J, Verdier V (1999) AFLP fingerprinting: an efficient technique for detecting genetic variation of Xanthomonas axonopodis pv. manihotis. Microbiology 145:107-114.

Restrepo S, Duque MC, Verdier V (2000) Characterization of pathotypes among isolates of Xanthomonas axonopodis pv. manihotis in Colombia. Plant Pathology 49:680-687.

Rubio JSR, Carrascal CEL, Melgarejo LM (2017) Physiological behavior of cassava plants (Manihot esculenta Crantz) in response to infection by Xanthomonas axonopodis pv. manihotis under greenhouse conditions. Physiological and Molecular Plant Pathology 100: 136-141.

Sikirou R (1999) Epidemiological investigations and development of integrated control methods of bacterial blight of cowpea caused by Xanthomonas campestris pv. vignicola. Ph.D thesis Submitted to University of Göttingen, Germany.

Tabot S (1995) Bacterial blight of cassava (Manihot esculenta Crantz) in the drier savannas of Nigeria. MSc thesis submitted to Ahmadu Bello University, Zaria, Nigeria.

Trenbath BR (1976) Plant interactions in mixed crop communities. In: Papendick RI, Sanchez PA, Triplett GB (Eds.), Multiple Cropping. Madison, American Society of Agronomy, Special Publication 27:129-164.

Vauterin L, Hoste B, Kersters K, Swings J (1995) Reclassification of Xanthomonas. International Journal of Systematic Bacteriology 45:472-489.

Winstead NN, Kelman A (1952) Inoculation technique for evaluating resistance to Pseudomonas solanacearum. Phytopathology 42:628-634

Wydra K, Fessehaie A, Fanou A, Sikirou R, Janse JD, Rudolph K (1998a) Variability of strains of Xanthomonas campestris pv. manihotis $(\mathrm{Xcm})$, incitant of cassava (Manihot esculenta Crantz) bacterial blight, from different geographic origins in pathological, physiological, biochemical and serological characteristics. In: Mahadevan A (Ed.) Plant Pathogenic Bacteria. Proceeding of 9th
International Conference, Centre for Advanced Study in Botany, University of Madras, India. Pp. 317-323.

Wydra K, Fanou A, Dixon AGO (2001a) Effect of cassava bacterial blight on cassava root yield in different ecozones and influence of the environment on symptom development. In: Akoroda MO, Ngeve JM (Eds.), Root Crops in the 21st Century. Proceedings of the 7th triennial Symposium of the International Society for Tropical Root Crops-Africa Branch (ISTRC-AB), Cotonou, Bénin 11 - 17 October 1998, Pp 562 - 569.

Wydra K, Fanou A, Sikirou R, Zandjanakou M, Zinsou V, Rudolph K (2001b) Integrated control of bacterial diseases of cassava and cowpea in West Africa. In: De Boer, Solke H (Eds) 10th International Conference on Plant Pathogenic Bacteria, Charlottetown, Prince Edward Island, Canada july 23-27, 2000, Kluwer Academic Publishers Pp 280-287.

Wydra K, Msikita W (1998) Overview of the present situation of cassava diseases in West Africa. In: Akoroda MO, Ekanayake IJ (Eds.), Proceedings of the $6^{\text {th }}$ Triennal Symposium of the International Society for Tropical Root Crops. Africa Branch, Lilongwe, Malawi, 22 - 28 October 1995, Pp. 198-206.

Wydra K, Zinsou V, Fanou A (1998b) The expression of resistance against Xanthomonas campestris pv. manihotis, incitant of cassava bacterial blight, in a resistant cassava variety compared to a susceptible variety. In: Mahadevan A (Ed). Plant Pathogenic Bacteria. Proc. 9th International Conference. Centre for Advanced Study in Botany, University of Madras, India. Pp. 583-592

Wydra K, Verdier V (2002) Occurrence of cassava diseases in relation to environmental agronomic and plant characteristics. Agriculture, Ecosystems and Environment 93:211-226.

Zandjanakou-Tachin M, Fanou A, Le Gall P, Wydra K (2007) Detection, Survival and Transmission of Xanthomonas axonopodis pv. manihotis and $X$. axonopodis pv. vignicola, Causal Agents of Cassava and Cowpea Bacterial blight, respectively, in/by Insect Vectors. Journal of Phytopathology 155:159 - 169.

Zinsou V (2001) Studies on the expression of resistance of cassava genotypes - including individuals of the mapping population - to cassava bacterial blight. MSc thesis. University of Göttingen, Germany.

Zinsou V, Wydra K, Ahohuendo B, Hau B (2004) Effect of soil amendments, intercropping and planting time in combination on the severity of cassava bacterial blight and yield in two ecozones of West Africa. Plant Pathology 53:585-595. Doi: 10.1046/j.00320862.2004.01056.x 